\title{
Relative efficacy of synthetic insecticides against sucking insect pests of chilli crop
}

\author{
Riaz Ahmed Parhyar ${ }^{1}$, Jan Muhammad Mari ${ }^{1}$, Aslam Bukero ${ }^{2 *}$, Abdul \\ Ghani Lanjar' ${ }^{1}$, Moazam Hyder ${ }^{1}$, Nangial Khan ${ }^{3}$, Abdul Aziz Bukero ${ }^{2}$ \\ and Habib Ullah Soomro ${ }^{1}$
}

1. Department of Plant Protection, Sindh Agriculture University Tandojam-Pakistan

2. Department of Entomology, Sindh Agriculture University Tandojam-Pakistan

3. Department of Agronomy, The University of Agriculture Peshawer-Pakistan

*Corresponding author's email: bukero786@gmail.com

Citation

Riaz Ahmed Parhyar, Jan Muhammad Mari, Aslam Bukero, Abdul Ghani Lanjar, Moazam Hyder, Nangial Khan, Abdul Aziz Bukero and Habib Ullah Soomro. Relative efficacy of synthetic insecticides against sucking insect pests of chilli crop. Pure and Applied Biology. Vol. 8, Issue 4, pp2248-2256.

http://dx.doi.org/10.19045/bspab.2019.80170

\begin{tabular}{llll}
\hline \hline Received: 23/05/2019 & Revised: 14/07/2019 & Accepted: 18/07/2019 & Online First: 23/07/2019 \\
\hline \hline
\end{tabular}

\section{Abstract}

The experiment was conducted to evaluate relative efficacy of synthetic insecticides against sucking insect pests of chilli crop at Bozdar Agriculture Farm, Distrcict Tando Allahayar during-2015. The chilli variety Advanta-509 was sown and treated with insecticides $\mathrm{T} 1=$ Deligate (Spinetoram) 25 water dispersible granule (WG) $4 \mathrm{mg} / 1$ lit water, $\mathrm{T} 2=$ Novastar (Bifenthrin + Abamectin) 11.5 emulsifiable concentrate (EC) $5 \mathrm{ml} / 1$ lit. Water and $\mathrm{T} 3=$ Transfarmer (Sulfoxaflor) $50 \mathrm{WG} 3 \mathrm{mg} / 1$ lit water of water at 1 DAS, 4 DAS, 7 DAS and 10 DAS (Days after Spray) intervals in each treatment. The results indicated that spinetoram and bifenthrin + abamectin insecticides was found best for reduction in thrip per leaf and flower population as compare to sulfoxaflor insecticides. The result further revealed that a bifenthrin + abamectine insecticide was found more excellent for whiteflies reduction in population followed by spinetoram and sulfoxaflor insecticides. Similarly, a sulfoxaflor insecticide was declared more excellent for management of aphid in chilli crop followed by bifenthrin + abamectin and spinetoram insecticides. The highest average yield was obtained plot treated with insecticide sulfoxaflor followed by insecticides Bifenthrin + Abamectine, spinetoram and control (Untreated), respectively. The analysis of variance of results indicated that there is no significant $(\mathrm{P}<0.05)$ difference in yield obtained from plot treated with insecticide, however, the control (untreated) plot significantly $(\mathrm{P}<0.05)$ different than insecicide.

Keywords: Abamectine; Bifenthrin; Chilli; Suking Insects; spinetoram; sulfoxaflor Introduction

Chilli (Capsicum annuum L.) is cultivated as vegetable crop in Rabi and Kharif season in different parts of the world like Thailand, China, India as well as Pakistan. This is used as green and dry chillies as spices for the making the different foods. Dry chilli is used in curry powder, sauces and pickles. In Pakistan it is also used in the cooking varieties of foods as spice in red and green form. Among them occurrence of viral diseases and effects caused by insect pests are important. The populations of pest on chilli crop have been about 293 insects and mite species damaging the field crop as well as storage [1]. The area and production have been raised, per unit yield of chilli crop is very low production is affected by the several insect pests in the field like: aphid (also 
known as green peach aphid), white flies, capsid bugs, thrips, cutworm, gram caterpillar, and more. Therefore, monitoring favorable environmental conditions of aphid breeding is essential regularly in chilli crop. To reduce the infestation level of aphid uesd currently applying various non-chemical approaches when during severe condition these approaches are not enough. In severe infestation, different systemic insecticides, like, melathion, phosphamidon and dimecron are injudiciously used for sapsucking insects like aphids but their efficacy is questionable. Imidacloprid, a new class of neonicotinoid insecticides, is potently replaced different toxic and hazardous insecticides with due to their unique mode of action (nicotinic acetylcholine receptor agonist or acetylcholine mimic) and comparatively less toxicity for human and environment. Therefore, some recent studies show that imidacloprid gives an outstanding result against sucking insects [2-5]. Works immediately after application even with low concentrations these types of insecticides are known as imidacloprid. While insecticidal molecules enter into the central nervous system by the sucked sap, they bind with the nicotinic receptor aganists sucked sap and eventually produce excess amount of acetylcholine, a potent neurotransmitter in the insects' then after central nervous system which continuously produce signalling through synapse, and ultimately the affected insects die due to the tremor, and paralysis. The exeriment was conducted in the field to evaluate the effect of synthetic insecticidal efficacy against sucking complex of chilli crop.

\section{Materials and methods}

The experiment was conducted at Bozdar Agriculture Farm, Distrcict Tando Allahayar during 2015. The chilli variety Advanta-509 was transplanted from mother field and then sown on ridges with plant to plant distance 1.5 feet and row to row 2.5 feet on 2000 sq.ft. plot. The plot divided into ten sub plots (200 sq.ft. each) including control.

The observation was taken from randomly selected 5 plants from each sub plot. From each plant 10 leaves and 10 flowers were examined for sucking insect pests. The experimental design was Randomized Complete Block Design (RCBD) with three replications. There were three treatment i.e. $\mathrm{T}_{1=}$ Deligate (spinetoram) $25 \mathrm{WG} 4 \mathrm{mg} / 1$ lit. water, $\mathrm{T}_{2}=$ Novastar (Abamectin + Bifenthrine) 11.5EC 5 $\mathrm{ml} / 1$ lit water and $\mathrm{T}_{3}=$ Transfarmer

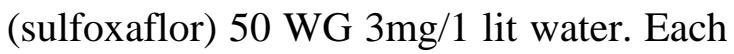
insecticide was sprayed with the ten days intervals according to the given dose. The observation was taken before and after spray of insecticides in the chilli crop at 1 DAS, 4 DAS, 7 DAS and 10 DAS (Days after Spray) intervals in each treatment. The yield of treated and untreated (control) plots was compared.

The reduction percent population was calculated by using Abbott's formula [6].

Reduction $\%=(1-\underline{\mathrm{n} \text { in T } \text { after treatment })} \times 100$ $\mathrm{n}$ in Co after treatment

\section{Results}

\section{Impact of insecticides on population of thrip, Scritothrip dorsalis \\ Leaf}

The result presented in (Table 1) indicated that the population of thrip 3.4/leaf was recorded before application of insecticide spinetoram 25 WG. After application of insecticide the population drastically reduced 0.28/leaf after 10 DAS (Days After Spary) followed by $0.55 /$ leaf, 0.78/leaf and 1.4/leaf after exposures of insecticide at 7 DAS, 4 DAS and 1 DAS, respectively. The highest reduction was recorded $96.45 \%$ after exposures of insecticide at 10 DAS followed by 91.13 , 87.21 and 73.58 after 7 DAS, 4 DAS and 1 DAS, respectively. The result further revealed that the population of thrip 4.8/leaf was observed before spray of bifenthrin + abamectin 56 EC. The population gradually declined and reached its maximum limit 0.96/leaf after exposures of insecticide at 7 DAS (Days 
After Spary) followed by $1.51 /$ leaf and 2.4/leaf at 4 DAS and 1 DAS, respectively. The population of thrip again rebuild after 10 DAS exposures of insecticides. The maximum reduction was observed $84.52 \%$ after exposures of insecticide at 7 DAS followed by $75.25 \%$ and $54.72 \%$ at 4 DAS and 1 DAS, respectively. Similarly, the data further depicted that the insecticide sulfoxaflor was applied for the management of sucking insect pests in chilli crop. The population of described insect pest was recorded 3.89/leaf before application of insecticide. After the exposures of insecticide, it slightly declined and reached its minimum limit 2.89/leaf, 2.67/leaf and 2.95/leaf at exposures of insecticide after application at intervals of 7 DAS, 4 DAS and 1 DAS, respectively. The population of thrip again started to rebuild after 10 DAS exposure intervals of insecticide. In the light of above observation, it was seen that spinetoram and bifenthrin + abamectin insecticides was found best for reduction in population as compare to sulfoaxaflor insecticides. The population of insect pest in the control plot slightly reduced due to abiotic and biotic factors. The analysis of variance indicated that all insecticides and interval periods are significantly $(P<0.05)$ different from each other.

Table 1. Effect of insecticides on the population of thrip, Scritothrip dorsalis in chilli crop.

\begin{tabular}{|c|c|c|c|c|c|c|c|}
\hline \multirow{2}{*}{$\begin{array}{l}\text { Plant } \\
\text { Parts }\end{array}$} & \multirow{2}{*}{ Treatments } & \multirow{2}{*}{ 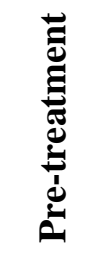 } & \multicolumn{4}{|c|}{ Post- treatment (Days) } & \multirow{2}{*}{ 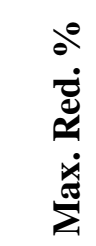 } \\
\hline & & & 1DAS & 4DAS & 7DAS & 10DAS & \\
\hline \multirow{4}{*}{ Leaf } & $\mathrm{T}_{1=}$ Spinetoram & 3.5 & $\begin{array}{c}1.40 \mathrm{f} \\
(73.58)\end{array}$ & $\begin{array}{l}0.78 \mathrm{~h} \\
(87.21)\end{array}$ & $\begin{array}{r}0.55 \mathrm{i} \\
(91.13) \\
\end{array}$ & $\begin{array}{c}0.28 \mathrm{i} \\
(96.45) \\
\end{array}$ & 96.45 \\
\hline & $\begin{array}{l}\mathrm{T}_{2}=\text { Abamectin } \\
+ \text { Bifenthrine }\end{array}$ & 4.8 & $\begin{array}{l}2.40 \mathrm{e} \\
(54.72)\end{array}$ & $\begin{array}{c}1.51 \mathrm{f} \\
(75.25)\end{array}$ & $\begin{array}{c}0.96 \\
(84.52) \\
\end{array}$ & $\begin{array}{l}1.31 \mathrm{fg} \\
(83.40)\end{array}$ & 83.40 \\
\hline & $\mathrm{T}_{3=}$ Sulfoxaflor & 3.89 & $\begin{array}{l}2.95 \mathrm{~d} \\
(44.34)\end{array}$ & $\begin{array}{l}2.67 \mathrm{de} \\
(56.23)\end{array}$ & $\begin{array}{c}2.89 \mathrm{~d} \\
(53.39)\end{array}$ & $\begin{array}{l}2.95 \mathrm{~d} \\
(62.61)\end{array}$ & 62.61 \\
\hline & $\mathrm{T}_{4}=$ Control & 4.1 & $5.3 \mathrm{c}$ & $6.1 \mathrm{~b}$ & $6.2 \mathrm{~b}$ & $7.89 \mathrm{a}$ & ----- \\
\hline \multirow{4}{*}{ Flower } & $\begin{array}{c}\mathrm{T}_{1=} \text { Spinetoram } \\
25 \mathrm{WG}\end{array}$ & 2.8 & $\begin{array}{c}0.89 \mathrm{i} \\
(72.27)\end{array}$ & $\begin{array}{c}0.42 \mathrm{j} \\
(89.88)\end{array}$ & $\begin{array}{c}0.31 \mathrm{j} \\
(93.92)\end{array}$ & $\begin{array}{l}0.21 \mathrm{jk} \\
(96.72)\end{array}$ & 96.72 \\
\hline & $\begin{array}{l}\mathrm{T}_{2=} \text { Abamectin } \\
\text { + Bifenthrine }\end{array}$ & 3.1 & $\begin{array}{c}1.65 \mathrm{f} \\
(48.60)\end{array}$ & $\begin{array}{r}1.05 \mathrm{~g} \\
(74.70) \\
\end{array}$ & $\begin{array}{r}0.89 \mathrm{i} \\
(82.55) \\
\end{array}$ & $\begin{array}{l}1.20 \mathrm{gh} \\
(81.25)\end{array}$ & 82.55 \\
\hline & $\mathrm{T}_{3=}$ Sulfoxaflor & 2.98 & $\begin{array}{c}1.44 \mathrm{f} \\
(55.14)\end{array}$ & $\begin{array}{c}1.56 \mathrm{f} \\
(62.41)\end{array}$ & $\begin{array}{l}2.23 \mathrm{e} \\
(56.27)\end{array}$ & $\begin{array}{c}2.89 \mathrm{e} \\
(54.84)\end{array}$ & 62.41 \\
\hline & $\mathrm{T}_{4=}$ Control & 2.87 & $3.21 \mathrm{~d}$ & $4.15 \mathrm{c}$ & $5.10 \mathrm{~b}$ & $6.40 \mathrm{a}$ & ----- \\
\hline
\end{tabular}

\section{Flower}

The result described in (Table 1) showed that the population of thrip was observed 2.8/flower before application of insecticide spinetoram 25 WG. The population significantly reduced $0.21 /$ leaf after foliar application of insecticide at 10 DAS (Days After Spary) interval period followed by 0.31/leaf, 0.42/leaf and 0.89/leaf at exposing periods 7 DAS, 4 DAS and 1 DAS, respectively. The highest reduction in population was seen $96.72 \%$ after exposures of insecticide at 10 DAS followed by 93.92, 89.88 and 72.27 after 7 DAS, 4 DAS and 1 DAS, respectively. The result further depicted that the thrip population was recorded 3.1/leaf before application of bifenthrin + abamectin 56 EC. The population drastically reduced and reached 0.98/leaf after exposures of insecticide at 7 DAS (Days After Spary) followed by $1.05 /$ leaf and $1.65 /$ leaf at 4 
DAS and 1 DAS, respectively. After exposure of 10 DAS interval period of insecticides insect pest population again started to reappear in chilli crop. The highest reduction in population $82.5 \%$ was recorded at 7 DAS after exposures of insecticide followed by $74.70 \%$ and $48.60 \%$ at 4 DAS and 1DAS, respectively. The result further revealed that the population of described insect pest was recorded 2.98/leaf before application of sulfoxaflor insecticide. The insect pest slightly declined after the exposures of insecticide and seen 1.44/leaf and 1.56/leaf, at 1 DAS and 4 DAS exposures interval of insecticide. Whereas population of thrip gradually re-establish after 7 DAS exposure intervals of insecticide. Similarly, the findings of presented results indicated that insecticides spinetoram and bifenthrin + abamectin were found most excellent for reducing thrip population as compare to sulfoaxaflor insecticide. However, in the untreated (control) plot population of insect pest reduced slightly due to abiotic and biotic factors. The analysis of variance of result showed that all insecticides and interval periods are significantly $(P<0.05)$ different from each other.

\section{Impact of insecticides on population of whitefly, Bemisia tabaci \\ Leaf}

The result prescribed in (Table 2) showed that the pre-treatment population of whitefly 2.3/leaf was observed before exposure of insecticide spinetoram 25 WG. The population of whitefly declined drastically reached its minimum limit 1.21/leaf after 4 DAS (Days After Spary) and 1.56/leaf after exposures of insecticide at 4 DAS and 1 DAS, respectively. The maximum reduction was recorded $64.45 \%$ after insecticide exposures at 4 DAS. The population of insect pest gradually increased 2.0/leaf after 7 DAS. The result of present data revealed that the population of whitefly 2.1/leaf was recorded before spray of bifenthrin + abamectin 56 EC. The population drastically reduced and reached its lowest limit 0.67/leaf at 7 DAS (Days After Spary) followed by 0.76/leaf and 0.96/leaf and 0.98/leaf at 10 DAS, 1 DAS and 4 DAS, respectively. The population of whitefly reinstate after 10 DAS intervals after insecticide application. The highest reduction was seen $84.46 \%$ after exposures of insecticide at 10 DAS followed by $83.74 \%, 71.59 \%$ and 67.01 at 7 DAS, 4 DAS and 1DAS, respectively. The result further showed that the population of whitefly was recorded 2.56/leaf before application of sulfoxaflor insecticide. After the exposures of insecticide, the population of whitefly slightly reduced and reached its minimum limit 1.45/leaf and 1.89/leaf after exposures of insecticide at 4 DAS and 1 DAS, respectively. The population of whitefly reinstate after 7 DAS intervals of insecticide exposure. The highest reduction in population of whitefly was observed $57.97 \%$ at 4 DAS after insecticide exposure. It was reviewed after the above narrated results it was observed that bifenthrin + abamectin insecticides was found more excellent for whiteflies reduction in population followed by spinetoram and sulfoxaflor insecticides. The population of insect pest in the control plot slightly reduced due to abiotic and biotic factors. The analysis of variance showed that there is significantly $(P<0.05)$ among insecticides and interval periods of insecticides application.

\section{Flower}

The result further revealed in (Table 2) indicated that the population of whitefly was recorded 0.35/flower before application of insecticide spinetoram 25 WG. The population of whitefly significantly reduced $0.11 /$ flower after foliar application of insecticide at 4 DAS (Days After Spary) interval period followed by $0.12 /$ leaf, $0.2 /$ flower and 0.21/flower at 7 DAS, 10 DAS and 1 DAS, respectively. The highest reduction was recorded $63.33 \%$ at 4 DAS after exposure of insecticide followed by 47.83, 40.0 and 33.33 after 7 DAS, 1 DAS and 10 DAS, 
respectively. The result further depicted that the whitefly population was recorded 0.48/flower before application of bifenthrin + abamectin 56 EC. The population gradually decreased 0.04/flower after application of insecticide at 7 DAS (Days After Spary) followed by $0.05 /$ flower, 0.1/flower and 0.14/flower at 10 DAS, 4 DAS and 1 DAS, respectively. The maximum reduction in population $83.33 \%$ was observed at 10 DAS after intervals of application of insecticide followed $82.61 \%, 66.67 \%$ and $60.0 \%$ at 7 DAS, 4 DAS and 1DAS, respectively. The data further indicated that the population of whitefly was observed 0.51/flower before application of sulfoxaflor insecticide. The insect pest gradually decreased after the exposures of insecticide and seen 0.11 /flower followed by 0.13 /flower, 0.21 /flower at 7 DAS, 10 DAS and 1 DAS exposures of insecticide. Similarly, it was observed that from above discussed results that bifenthrin + abamectin insecticides was found more excellent for whiteflies management followed by spinetoram and sulfoxaflor insecticides. In the control plot the population of insect pest slightly reduced due to abiotic and biotic factors. The analysis of variance showed that there is significantly $(P<0.05)$ among insecticides and interval periods of insecticides application.

Table 2. Effect of insecticides on the population of whitefly, Bemisia tabaci in chilli crop

\begin{tabular}{|c|c|c|c|c|c|c|c|}
\hline \multirow{2}{*}{$\begin{array}{l}\text { Plant } \\
\text { Parts }\end{array}$} & \multirow{2}{*}{ Treatments } & \multirow{2}{*}{ } & \multicolumn{4}{|c|}{ Post- treatment (Days) } & \multirow{2}{*}{ 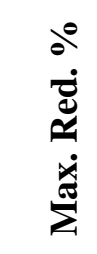 } \\
\hline & & & 1DAS & 4DAS & 7DAS & 10DAS & \\
\hline \multirow{4}{*}{ Leaf } & $\mathrm{T}_{1=}$ Spinetoram & 2.30 & $\begin{array}{r}1.56 \mathrm{~d} \\
(46.39) \\
\end{array}$ & $\begin{array}{r}1.21 \mathrm{e} \\
(64.93) \\
\end{array}$ & $\begin{array}{c}2.00 \mathrm{~d} \\
(51.46) \\
\end{array}$ & $\begin{array}{c}2.91 \mathrm{c} \\
(40.49) \\
\end{array}$ & 64.93 \\
\hline & $\begin{array}{c}\mathrm{T}_{2=} \\
\text { Abamectin+Bifenthrine }\end{array}$ & 2.10 & $\begin{array}{l}0.96 \mathrm{e} \\
(67.01)\end{array}$ & $\begin{array}{l}0.98 \mathrm{e} \\
(71.59)\end{array}$ & $\begin{array}{c}0.67 \mathrm{f} \\
(83.74)\end{array}$ & $\begin{array}{c}0.76 \mathrm{f} \\
(84.46)\end{array}$ & 84.46 \\
\hline & $\mathrm{T}_{3=}$ Sulfoxaflor & 2.56 & $\begin{array}{l}1.89 \mathrm{~d} \\
(35.05)\end{array}$ & $\begin{array}{l}1.45 \mathrm{de} \\
(57.97)\end{array}$ & $\begin{array}{l}2.12 \mathrm{~cd} \\
(48.54)\end{array}$ & $\begin{array}{l}3.98 \mathrm{~b} \\
(18.61)\end{array}$ & 57.97 \\
\hline & $\mathrm{T}_{4=}$ Control & 2.21 & $2.91 \mathrm{c}$ & $3.45 \mathrm{~b}$ & $4.12 \mathrm{ab}$ & $4.89 \mathrm{a}$ & ----- \\
\hline \multirow{4}{*}{ Flower } & $\mathrm{T}_{1=}$ Spinetoram & 0.35 & $\begin{array}{l}0.21 \mathrm{~b} \\
(40.00)\end{array}$ & $\begin{array}{r}0.11 \mathrm{c} \\
(63.33)\end{array}$ & $\begin{array}{c}0.12 \mathrm{c} \\
(47.83)\end{array}$ & $\begin{array}{l}0.20 \mathrm{~b} \\
(33.33)\end{array}$ & 63.33 \\
\hline & $\begin{array}{c}\mathrm{T}_{2=} \\
\text { Abamectin+Bifenthrine }\end{array}$ & 0.48 & $\begin{array}{l}0.14 \mathrm{c} \\
(60.00)\end{array}$ & $\begin{array}{l}0.10 \mathrm{~d} \\
(66.67)\end{array}$ & $\begin{array}{l}0.04 \mathrm{e} \\
(82.61)\end{array}$ & $\begin{array}{l}0.05 \mathrm{e} \\
(83.33)\end{array}$ & 83.33 \\
\hline & $\mathrm{T}_{3}=$ Sulfoxaflor & 0.51 & $\begin{array}{l}0.21 \mathrm{~b} \\
(40.00)\end{array}$ & $\begin{array}{l}0.11 \mathrm{c} \\
(63.33)\end{array}$ & $\begin{array}{c}0.13 \mathrm{c} \\
(43.48)\end{array}$ & $\begin{array}{l}0.21 \mathrm{~b} \\
(30.00)\end{array}$ & 63.33 \\
\hline & $\mathrm{T}_{4=}$ Control & 0.39 & $0.35 \mathrm{a}$ & $0.30 \mathrm{a}$ & $0.23 \mathrm{ab}$ & $0.30 \mathrm{a}$ & - \\
\hline
\end{tabular}

\section{Impact of insecticides on population of aphid, Myzus persicea \\ Leaf}

The result presented in (Table 3) showed that the pre-treatment populations of aphid were recorded 2.1/leaf before exposure of insecticide spinetoram 25 WG. The population of aphid decreased gradually and reached its lowest level 1.45/leaf after 4 DAS (Days After Spary) followed by 1.56/leaf, 1.81/leaf and 1.98/leaf after exposures of insecticide at 4 DAS and 1 DAS and 10 DAS, respectively. The highest reduction was observed $56.19 \%$ after insecticide exposures at 7 DAS. The population of aphid gradually increased after 7 DAS exposures of insecticide. The result further revealed that the pretreatment population of aphid 2.98/leaf was seen in plot treated with bifenthrin + 
abamectin 56 EC. The population of aphid gradually decreased at its minimum limit 0.89/leaf at 7 DAS (Days After Spary) followed by $1.01 /$ leaf and $1.23 /$ leaf and 1.54/leaf at 4 DAS, 10 DAS and 1 DAS, respectively. The aphid population again stated to rebuild after 10 DAS intervals after insecticide application. The highest reduction was observed $73.11 \%$ after exposures of insecticide intervals at 7 DAS followed by $67.63 \%, 66.02 \%$ and 46.71 at 4 DAS, 10 DAS and 1DAS, respectively. The result further indicated that before application of sulfoxaflor insecticide aphid was seen 2.87/leaf. After the application of insecticids the population of aphid drastically decreased and reached its lowest level $0.21 /$ leaf after exposures of insecticide at 7 DAS. The population of aphid re-establish after 7 DAS intervals of exposure of insecticide. The maximum reduction in population of aphid was recorded $93.66 \%$ at 7 DAS after insecticide exposure. In the light of above described findings it was narrated that sulfoxaflor insecticides was declared more excellent for management of aphid in chilli crop followed by emammectin+bifenthrine and spinetoram insecticides. The population of insect pest in the control plot slightly reduced due to abiotic and biotic factors. The analysis of variance of the data denoted that there is significantly $(P<0.05)$ difference among insecticides and interval periods of application of insecticides.

Table 3. Effect of insecticides on the population of aphid, Myzus persicea in chilli crop

\begin{tabular}{|c|c|c|c|c|c|c|c|}
\hline \multirow{2}{*}{$\begin{array}{l}\text { Plant } \\
\text { Parts }\end{array}$} & \multirow{2}{*}{ Treatments } & \multirow{2}{*}{ 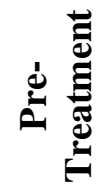 } & \multicolumn{4}{|c|}{ Post- treatment (Days) } & \multirow{2}{*}{ 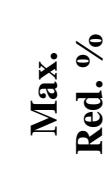 } \\
\hline & & & 1DAS & 4DAS & 7DAS & 10DAS & \\
\hline \multirow{4}{*}{ Leaf } & $\mathrm{T}_{1=}$ Spinetoram & 2.1 & $\begin{array}{l}1.81 \mathrm{c} \\
(37.37)\end{array}$ & $\begin{array}{c}1.56 \mathrm{~d} \\
(50.00)\end{array}$ & $\begin{array}{c}1.45 \\
(56.19)\end{array}$ & $\begin{array}{c}1.98 \mathrm{c} \\
(45.30)\end{array}$ & 56.19 \\
\hline & $\mathrm{T}_{2}=$ Abamectin + Bifenthrine & 2.98 & $\begin{array}{c}1.54 \mathrm{~d} \\
(46.71) \\
\end{array}$ & $\begin{array}{c}1.01 \mathrm{f} \\
(67.63)\end{array}$ & $\begin{array}{l}0.89 \mathrm{fg} \\
(73.11)\end{array}$ & $\begin{array}{l}1.23 \mathrm{de} \\
(66.02)\end{array}$ & 67.63 \\
\hline & $\mathrm{T}_{3=}$ Sulfoxaflor & 2.87 & $\begin{array}{l}0.89 \mathrm{fg} \\
(69.20)\end{array}$ & $\begin{array}{c}0.45 \mathrm{~g} \\
(85.58)\end{array}$ & $\begin{array}{c}0.21 \mathrm{~h} \\
(93.66)\end{array}$ & $\begin{array}{c}0.23 \mathrm{~h} \\
(93.65)\end{array}$ & 93.66 \\
\hline & $\mathrm{T}_{4=}$ Control & 2.48 & $2.89 \mathrm{~b}$ & $3.12 \mathrm{a}$ & $3.31 \mathrm{a}$ & $3.62 \mathrm{a}$ & ----- \\
\hline \multirow{4}{*}{ Flower } & $\mathrm{T}_{1=}$ Spinetoram $25 \mathrm{WG}$ & 1.89 & $\begin{array}{c}1.31 \mathrm{~b} \\
(34.83)\end{array}$ & $\begin{array}{l}1.10 \mathrm{bc} \\
(52.38)\end{array}$ & $\begin{array}{l}1.11 \mathrm{bc} \\
(55.42)\end{array}$ & $\begin{array}{c}1.24 \mathrm{~b} \\
(52.49)\end{array}$ & 55.42 \\
\hline & $\mathrm{T}_{2}=$ Abamectin + Bifenthrine & 1.67 & $\begin{array}{l}1.12 \mathrm{bc} \\
(44.28)\end{array}$ & $\begin{array}{c}0.98 \mathrm{~d} \\
(57.58)\end{array}$ & $\begin{array}{c}0.67 \mathrm{e} \\
(73.09)\end{array}$ & $\begin{array}{c}0.89 \mathrm{~d} \\
(65.90)\end{array}$ & 73.09 \\
\hline & $\mathrm{T}_{3=}$ Sulfoxaflor & 2.23 & $\begin{array}{c}0.56 \mathrm{e} \\
(72.14)\end{array}$ & $\begin{array}{c}0.37 \mathrm{e} \\
(83.98)\end{array}$ & $\begin{array}{c}0.18 \mathrm{f} \\
(92.77)\end{array}$ & $\begin{array}{l}0.22 \mathrm{de} \\
(91.57)\end{array}$ & 92.77 \\
\hline & $\mathrm{T}_{4=}$ Control & 1.91 & $2.01 \mathrm{ab}$ & $2.31 \mathrm{a}$ & $2.49 \mathrm{a}$ & $2.61 \mathrm{a}$ & ----- \\
\hline
\end{tabular}

\section{Flower}

The result narrated in (Table 3) indicated that the pre-treatment population of aphid was observed 1.89/flower before application of insecticide spinetoram 25 WG. The population of aphid slightly decreased 1.10/flower after exposure of insecticide at 4 DAS (Days After Spary) interval period followed by $1.11 /$ leaf, 1.24/flower and 1.31/flower at 7 DAS, 10 DAS and 1 DAS, respectively. The highest reduction in population of aphid was observed $55.42 \%$ at 7 DAS after exposure of insecticide followed by 52.49, 52.38 and 34.83 after 10 DAS, 4 DAS and 1 DAS, respectively. The result further revealed that the aphid population was seen 1.67/flower before application of bifenthrin + abamectin 56 EC. The aphid population frequently decreased $0.67 /$ flower after application of insecticide at 7 DAS (Days After Spary) followed by $1.11 /$ flower, 1.24/flower and 1.31/flower at 4 DAS, 10 DAS and 1 DAS, respectively. The highest 
reduction in population $73.09 \%$ was observed at 7 DAS after insecticide application intervals followed $65.90 \%$, $57.88 \%$ and $44.28 \%$ at 10 DAS, 4 DAS and 1DAS, respectively. The result further showed that the population of aphid was observed 2.23/flower before application of sulfoxaflor insecticide. The aphid population drastically reduced 0.18 /flower after the application of insecticide followed by $0.22 /$ flower, $0.37 /$ flower and 0.56 at 10 DAS, 4 DAS and 1 DAS exposures of insecticide. The results of above narrated findings showed that the insecticide sulfoxaflor insecticide was found more excellent for aphid management followed by that bifenthrin + abamectin and spinetoram insecticides. In the control plot the population of insect pest slightly reduced due to abiotic and biotic factors. The analysis of variance showed that there is $\quad$ significantly $\quad(P<0.05) \quad$ among insecticides and interval periods of insecticides application.

\section{Yield of chilies}

The result displayed in (Fig.1) indicated that the yield of green chillies yield was recorded in the plots treated with insecticides i.e. spinetoram, Bifenthrin + Abamectine and sulfoxaflor. The highest average yield was obtained $31.0 \mathrm{Kg} / \mathrm{plot}$ in the area treated with insecticide sulfoxaflor followed by $29.5,31.0$ and $14.8 \mathrm{~kg} / \mathrm{plot}$ treated with insecticides bifenthrin + abamectin, spinetoram and Control (Untreated), respectively. The analysis of variance of results indicated that there is no significant $(P<0.05)$ difference in yield obtained from plot treated with insecticide, however, the control (untreated) plot significantly $(P<0.05)$ different than insecticide.

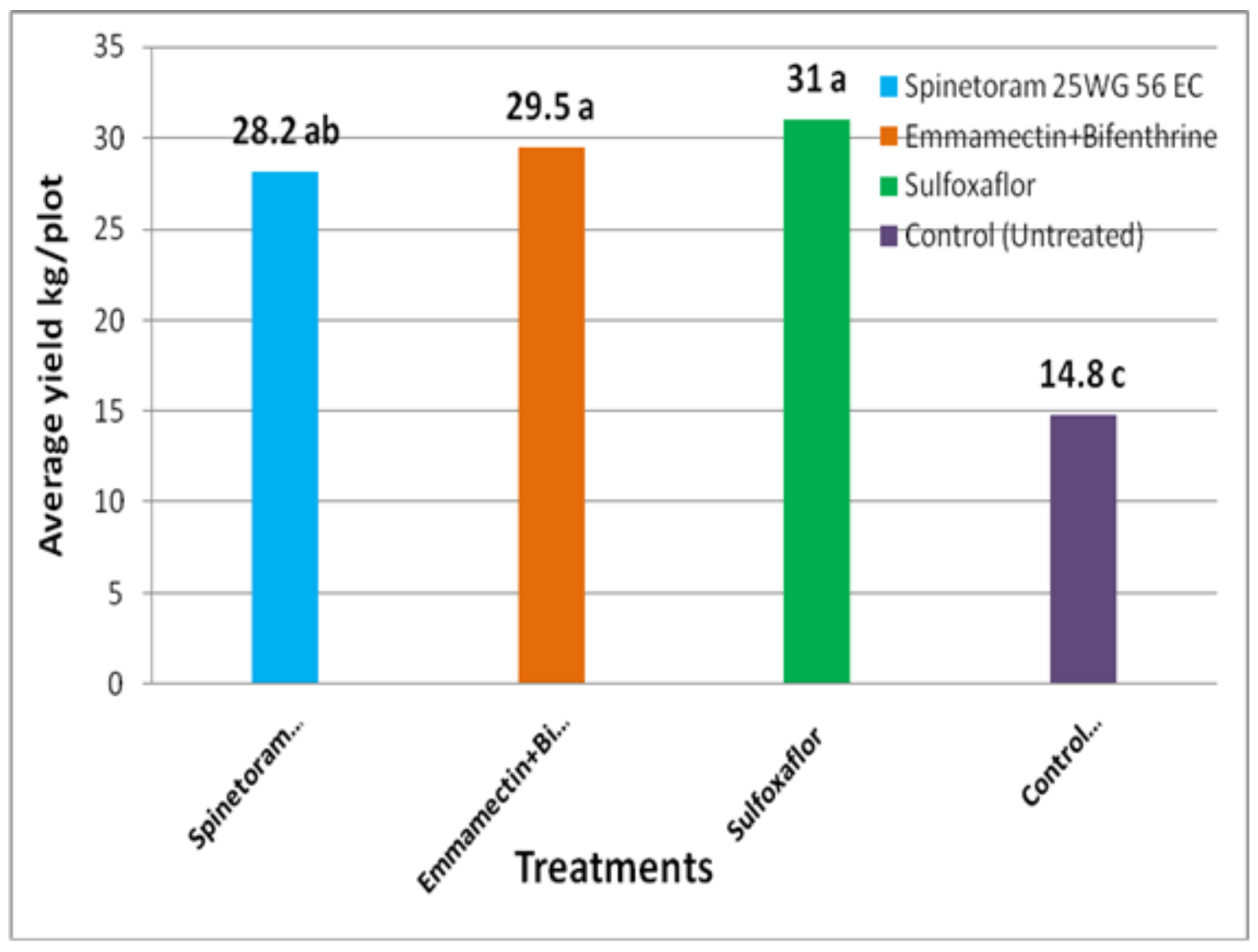

Figure 1. Average yield Kg/Pot of green chillies 


\section{Discussion}

The findings present results indicated that spinetoram and bifenthrin + abamectin insecticides was found best for reduction in thrip per leaf and flower population as compare to sulfoaxaflor insecticides. The population of insect pest in the control plot slightly reduced due to abiotic and biotic factors. The analysis of variance indicated that all insecticides and interval periods are significantly $(P<0.05)$ different from each other. The result further revealed that bifenthrin + abamectin insecticides were found more excellent for whiteflies reduction in population followed by spinetoram and sulfoxaflor insecticides. The population of insect pest in the control plot slightly reduced due to abiotic and biotic factors. The analysis of variance showed that there is significantly $(P<0.05)$ among insecticides and interval periods of insecticides application. Similarly, a sulfoxaflor insecticide was declared more excellent for management of aphid in chilli crop followed by bifenthrin + abamectin and spinetoram insecticides. The population of insect pest in the control plot slightly reduced due to abiotic and biotic factors. The analysis of variance of the data denoted that there is significantly $(P<0.05)$ difference among insecticides and interval periods of application of insecticides.

Our findings have conformity with [7] who also reported low leafhopper population with spinetoram $10 \%+$ sulfoxaflor 40\%WG @ 140 g.a.i/ha treatment. In the management of thrips spinetoram 10\%+ sulfoxaflor 40\%WG @ 140 g.a.i/ha found effective. These finding agreed with [8] who reported that spinetoram applied at 13.0 to $26.0 \mathrm{~g}$ a.i. /ha provided better control comparable to commercial standards under moderate infestation levels. Where as in our study spinetoram $10 \%+$ sulfoxaflor $40 \% \mathrm{WG}$ is superior because of their combined and novel mode of action as explained earlier. Das and Islam [9] reported that thiamethoxam+emamectin benzoate shown maximum efficacy against white flies and jassids and moderate effective was observed by using. Sarkar et al. [10] showed the effect of sucking complex such as, aphid, thrips and broad mite. The insceticide lubendiamide @ $0.2 \mathrm{ml} \mathrm{1-1}$, diafenthiuron@1g/l and neemazal T.S. @ $2.5 \mathrm{ml} \mathrm{l-1}$ were proved as most effective followed by spinosyn @ $0.3 \mathrm{ml} \mathrm{1-1,}$ abamectin@0.75 ml 1-1 and NPV@250 LE. Similarly, emamectin benzoate and Propargite were also moderate effective insecticides. Ali et al. [11] evaluated different strategies of aphids, jassids and white flies in potato. Against insect/pests of potato six insecticides were applied. Humanity of these pests above 85 percent showed all insecticidesofpotato. In aphids the highest $96.4 \%$ humanity caused by tender 10 EC and Sharp 25WP. The efficacy against jassids was higher tender $10 \mathrm{EC}$ than other insecticide that was about $88.7 \%$ followed by sharp 25WP. In case of white flies, the highest mortality was caused sharp 20SL, which was about 86.6 $\%$ and the lowest mortality $85.3 \%$ caused by talent. Tender 10EC and sharp 25WP should be applied for controlling aphids, jassids and white flies in potato crop.

\section{Conclusion}

From the above study it is concluded that insecticides spinetoram showed maximum reduction while bifenthrin + abamectin was found better for reduction in thrip per leaf and flower population as compare to sulfoaxaflor insecticides. The insecticide sulfoxaflor was found excellent for management of aphid in chilli crop and gave maximum yield as compared to control (untreated) followed by bifenthrin + abamectin and spinetoram insecticides. Therefore, insecticides spinetoram, emmaectin+bifenthrine and sulfaxoflor are suggested against thrips, whiteflies and aphid to obtain the better yield of green as well as red chillies.

\section{Authors' contributions}

Conceived and designed the experiments: RA Parhyar \& A Bukero, Performed the experiments: RA Parhyar \& A Bukero, JM 
Mari, Analyzed the data: AG Lanjar \& AA Bukero, Contributed materials/ analysis/ tools: RA Parhyar, A Bukero \& HU Soomro, Wrote the paper: M Hyder \& N Khan.

\section{References}

1. Anonymous (1987). Progress Report1987 for Asian Vegetable Research and Development Centre, Taiwan. 7779.

2. Elbert A, Overbeck B, Booker, Hertwig J \& Erdelen G (1991). Imidacloprid new systemic insecticide. $P$ flanzenschutz Nachrichten Bayer 11: 113-136.

3. Dewar AM, Reid LA, Hallswarth PB \& Smith HG (1992). Effect of imidacloprid on transmission of viruses by aphids in sugar beet. British Crop Prot. Council, Farnham UK. 563-568.

4. Joshi NK \& Sharma VK (2009). Efficacy of imidacloprid (Confidor 200 SL) against aphids infesting wheat crop. J Cen Euro Agric 10(2): 217-222.

5. Kencharaddai AV \& Balikari RA (2012). Effect of imidacloprid and thiamethoxam treated stored seeds on sucking pests in Sunflower. Annals Plant Prot Sci 20:107-113.
6. Abbott WS (1925). A method of computing the effectiveness of an insecticide. J Econ Ento 18: 265-267.

7. Ambarish SC, Shashikumar, Somu G \& Shivaray N (2017). Studies on the Bio-efficacy of new insecticide molecules against insect pests in cotton aicrp on cotton. $J$ of Ento and Zoo Stu 5(6): 544-548.

8. Siebert MW, Nolting S, Dripps JE, Walton LC, Cook DR, Stewart S, Gore J, Catchot AL, Lorenz G, Leonard BR \& Herbert A (2016). Efficacy of Spinetoram against thrips (Thysanoptera: Thripidae) in seedling cotton, Gossypium hirsutum L. The J of Cott Sci 20: 309-319.

9. Das, G \& Islam T (2014). Relative efficacy of some newer insecticides on the mortality of jassid and white fly in brinjal. Inter $J$ of Res in Bio Sci 4(3):89-93.

10. Sarkar PK, Timsina GP, Rai $\mathrm{P} \&$ Chakrabarti S (2015). IPM modules of chilli (Capsicum annuum L.) in Gangetic alluvial plains of West Bengal. J Crop and Weed 11: 167170.

11. Ali H, Shah RA, Zeb Q, Badshah H \& Rehman M (2011). Evaluation of some chemicals against the aphids, jassids and white flies in potato. Sci Inter Lah 23(1): 67-69. 